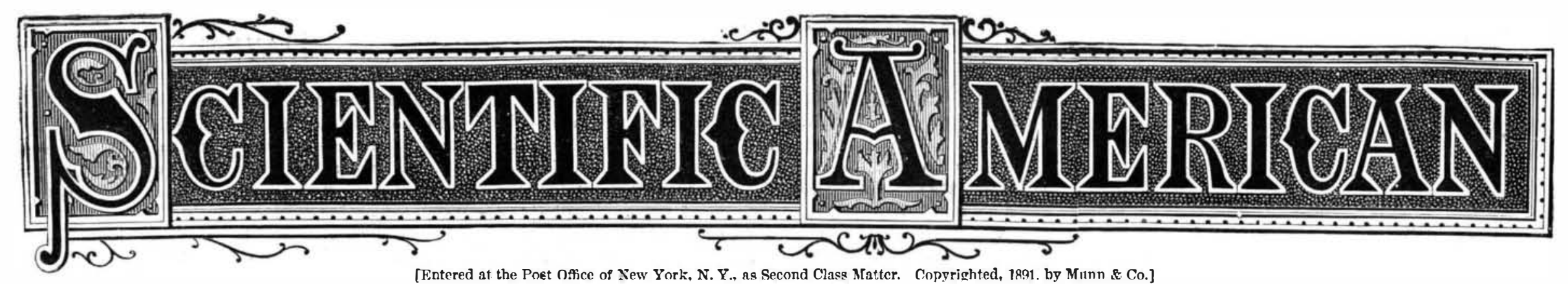

A WEEKLY JOURNAL OF PRACTICAL INFORMATION, ART, SCIENCE, MECHANICS, CHEMISTRY, AND MANUFACTURES.

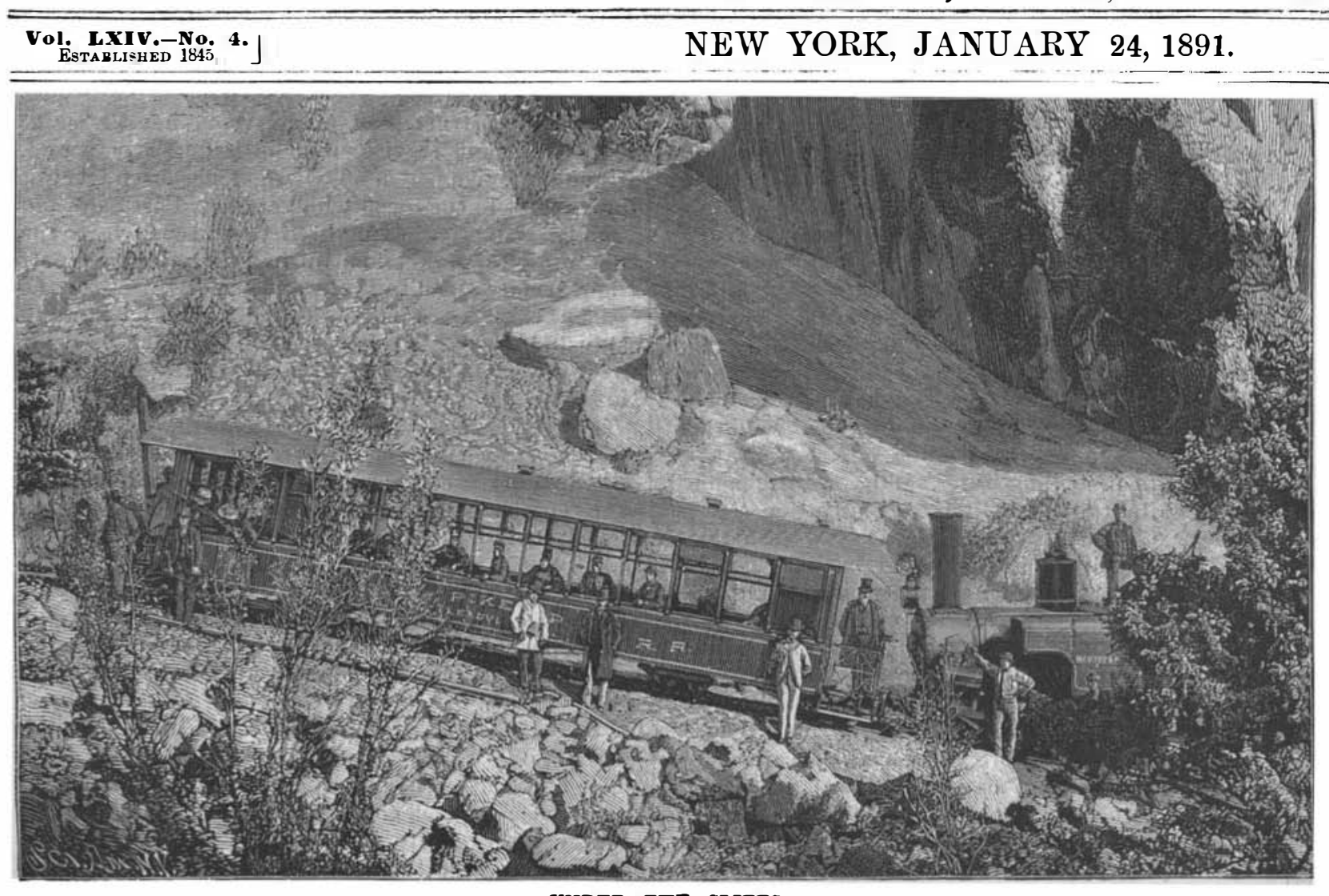

UNDER THE CLIFFS.

$[\underset{\text { W3.00 }}{\mathbf{A} \text { Y YEAT. R. }}$.

was not the first one. Seven years ago many thousand dollars were sunk in a futile attempt. The plan was to gain the summit by a light grade and smooth rails, which necessitated a much longur route.

Several miles of the grading were completed, when the plan was ahandoned.

The roadbed, crossing as it did so many waterways, was contiuually threatened with washouts. But the failures of the first company have only aided to pilot the present projectors to a wiser course.

Major John Hulbert, the president of the road, was the first to conceive the proper mode of construction, and he succeeded in interesting a number of railroad officials, whose roads, either by direct or indirect connection, would profit by a line to the summit of the peak. stock company was soon formed, surveys made, and the contract for the work let.

Mr. T. F. Richardson is the chief engineer of the work, and superintended the entire construction from the time of the first surveys until its completion.

Mr. Z. G. Simmons, of Kenosha, Wis., was the general contractor, with B. Lantry \& Sous, of Topeka, Kan subcontractors for the grading. The work of construction began September (Coratinued on page 55.)

THE MANITOU AND PIKE'S PEAK RAILWAY. BY YRED. R. HASTINGS.

When Zebulon Pike, with his small band of followers, pierced the trackless waste in 1806 and gazed upon the mountain which bears his name, he little dreamed that in future years the ingenuity and enterprise of man would surmount the obstacles of nature, and the same century would see the steel bands of a railway laid up the ascent and a ponderous locomotive hauling its preciousloadof human freight from the base tothe summit. The Manitou and Pike's Peak Rail way is now a reThe Manitou and Pike's Peak Rail way is now a reality. The trial trip over the entire line was made
October 20 last, and subsequent operation by passenger October 20 last, and subsequent operation by passenger traine over a large portion of the road has proved the
full success of the undertaking. The attempt so successfully carried out to construct a railway up the peak
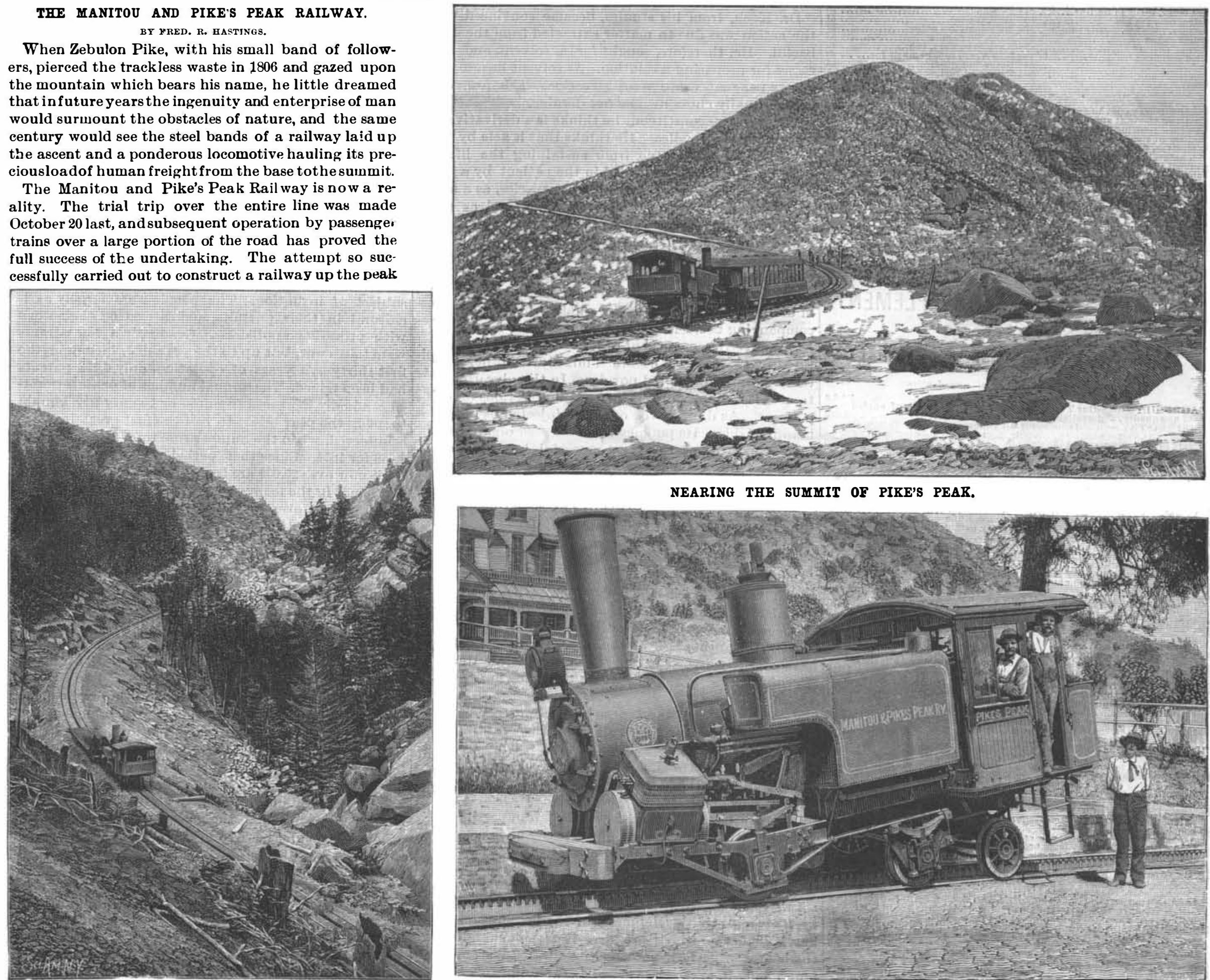

NEARING THE SUMMIT OF PIKE'S PEAK.

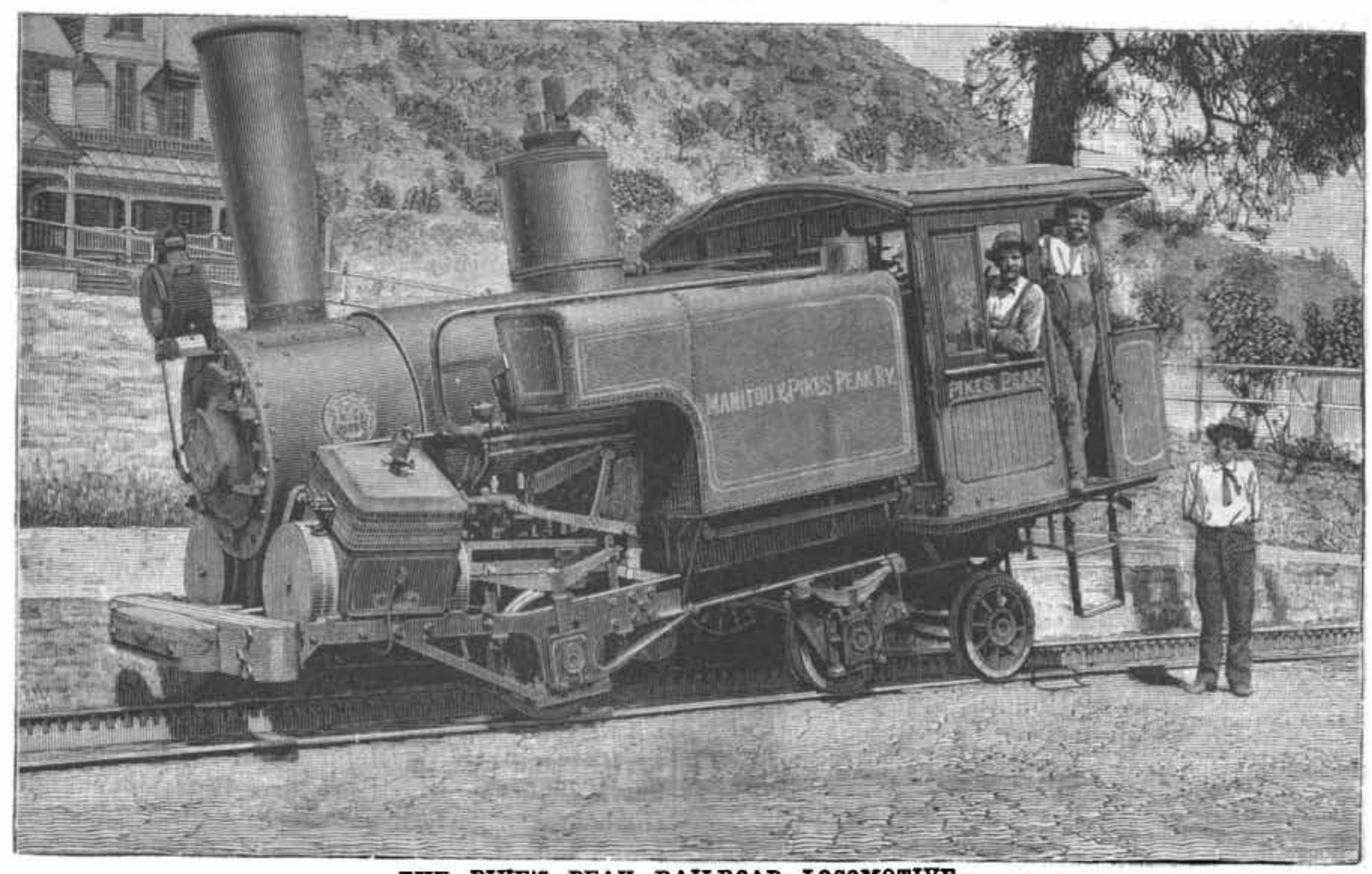

THE PIKE'S PEAK RAILROAD LOCOMOTIVE.

INCLINED RAILROAD TO THE SUMMIT OF PIKE'S PEAK. 
THE MANITOU AND PIKE'S PEAR RAILWAY.

(Continued from first page.)

25,1889 , the grading was completed August 4, 1890 and the track laying October 20,1890

When the construction of the roadbed began, eight hundred men and one hundred and fifty horses and mules were put in service.

All provisions, tools, and camping outfits were transported by trail to the various camps along the line on the backs of mules and burros. Only those fauniliar with the Rocky Mountain region can form an adequate conception of the difficulty of the undertaking. 'The precipitous cliff of solid granite, the deep canons and ravines, the vast, deep fields of snow, seem ohstacles set by Nature never to be surmounted by man.

The road is operated by the Abt cogwheel system. The maximum degree of curvature is 16 , or a curve with a radius of 359 feet. The length of the road is a few feet less than nine miles, of which two and threequarters miles are above timber line. The elevation of the station at Maniton is $6.563 \cdot 3$ feet, the summit of Pike's Peak 14,115.3 feet, the elevation overcome between the points being 7,252 feet. The roadbed is 15 feet wide, increased to 20 and 22 feet through cuts, thus giving protection, in case of derailment, from more serious accident.

No trestle work is used on the entire line. All bridges are built of iron, and were constructed by the Edgemoor Bridge Works, of Wilmington, Del.

The culverts are built of solid masonry and placed wherever necessary to guard against washouts.

The road is standard gauge. The T-rails weigh 40 pounds per yard, and are laid on red spruce ties, 9 feet long. The rack-rail is laid in the center between the T-rails, and consists of two continuous rails made up of parallel bars, each 80 inches long, of soft Bessemer steel, held in position by means of die-forged steel chairs, which are secured to the ties by wood screws. The parallel bars are set $15 \%$ inches apart, each containing seventeen teeth or cogs in their length, in which the pinions of the engines interlock $1 \frac{1}{4}$ inches (Fig. 1).

The bars vary in thickness from $7 / 8$ inch to $1 \frac{1}{4}$ inches, or from 21 to $31 \frac{1}{2}$ pounds per foot, the heavier bars being used on the steeper grades. The chairs are set 40 inches apart, each bar being doubly bolted to three chairs, in the middle and at either end. The bolt holes in the middle of the bars are of the same size as the bolts, while those at either end are drilled threeeightieths inch larger, to allow for expansion of the bars.

On account of the steepness of the grade and consequent tendency of the track to slide, both by its own constant weight as well as that of passing trains, also from expansion and contraction due to varying temperature, a very thorough system of anchorage has been carried out

In the entire length of the road 146 anchors are used, varying in distance one from another from 200 to 600 feet, according to the steepness of the grade, and are of two kinds. In some instances (Fig. 1) a pair of steel straps are secured to one of the chairs and attached by mean of a coupling adjustable in length to a turned
pin, $2 \frac{1}{2}$ inches in diapin, $2 \frac{1}{2}$ inches in dia-
meter and 2 feet long, which is leaded into the solid rock.

In the absence of a ledge of rock, a steel bar (Fig. 3) is set at the low er side of a tie, and from er side of a tie, and from this an oak timber of cross section 10 inches by 10 inches, and from 10 to 14 feet long, is carried downward at a steeper angle than the grade of the road, and thrusts either against a heavy oak timber embedded in the ballast at right angles to the first timber or against rock. The arrangement of th cogs is shown in Fig. 2. The engines, three in number, were built by the Baldwin Locomotive Works, of Philadelphia, and present a very diff erent appearance

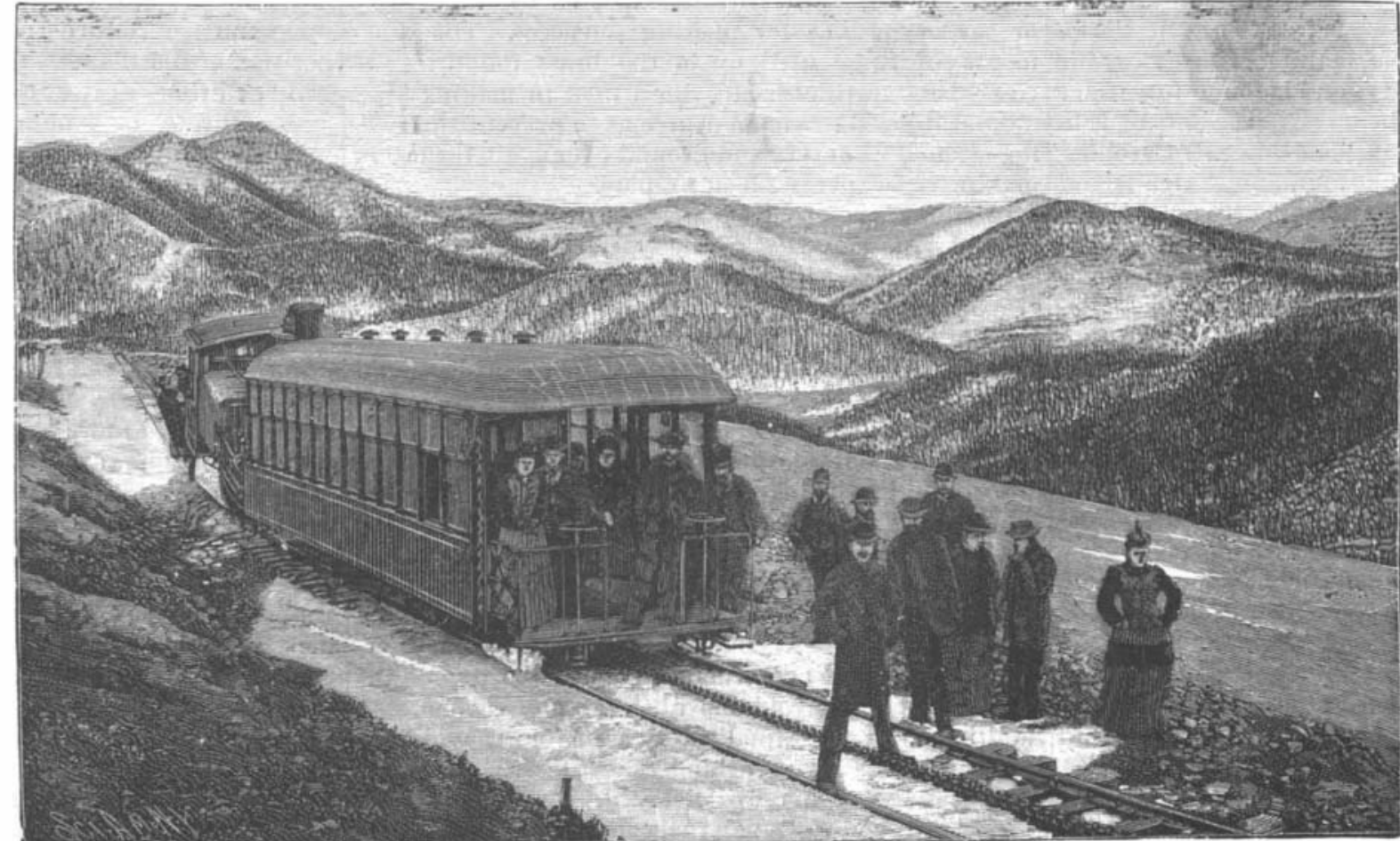

PIKE'S PEAK RAILWAY-THE RUN DOWN FROM WINDY POINT,

inches. The boiler has a 42 inch shell, and the flues The trip from Manitou to the summit occupies an are 7 feet long. The engines have 200 horse power, and are built to half an hour less time. The minimum speed of the stand level on a 16 per cent grade. There are three train is three miles per hour, and the maximum eight sets of double pinion brakes on each engine.

The power is transwitted by a main drum, which has The expense of constructing the entire road was teeth similar to the pinions, and works on the two back about half a million of dollars.

ets or pinions, the forward set of pinious being driven The company have ceased to operate regular trains y rod connection with the middle set. The two back for the winter. During the few weeks of the fall when
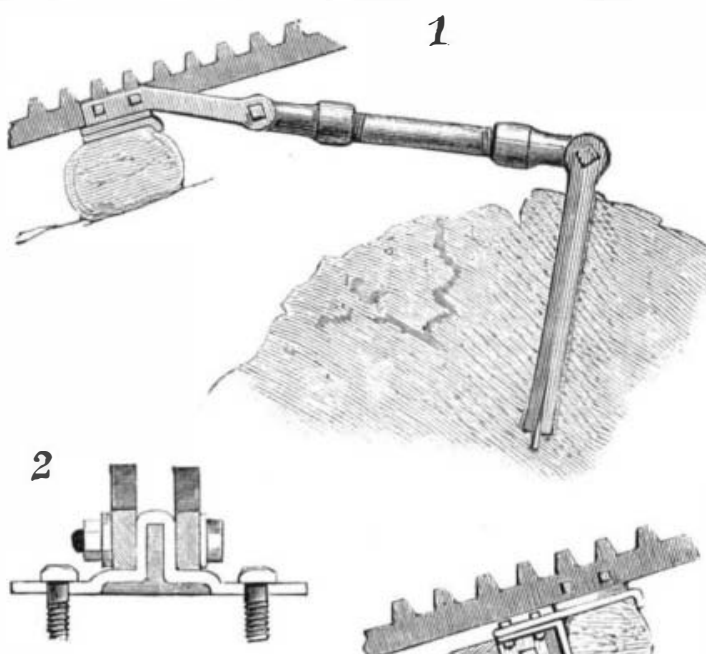

ts, which are connected with the main drum, furnish inions being principally to apply brake power.

In descending, the cylinders of the engine are used as $\mathrm{w}$

air compressors, a streaus of water being kept running into them continually to keep them from heating. By
controlling this compressed air, the speed of the train is regulated.

In addition, the two front sets of pinions have a peculiar steam brake connection which locks them instantly. The back pinion has a haud brake connestion which is capable of stopping the whole train in a few seconds time on heaviest grade. Each car has two hand from either end of the car, either one of which is apable of holding the whole train.

A brakeman is stationed at each brake during th Deration.

The cars, built by the Mason Manufacturing Works, of Springfield, Mass., are 43 feet long, $81 /$

ve a seating capacity of fifty people. for the winter. During the few weeks of the fall when
regular trains were run as far as the Half Way House, many people were carried over the line. The road will be open for the summer season about June 1 this year. Our illustrations are from photographs kindly furnished by Mr. Geo. E. Mellin.

\section{Was It a Telephone?}

In Porter's "Knights of Malta," vol. $i_{\text {., }}$ chap. siv., we read: "Shafts were sunk in various directions and galleries driven forward beneath the principal botions. Martinigo had, however, foreseen the probability of this mode of approach, and the counter mines which he had prepared before the commencement of the siege materially assisted him in opposing them. By the simple aid of the distended parchment of a drum head he was enabled to detect the vicinity of the enewy's miners when at work, through the vibrations of the earth, and his measures were taken accordingly to destroy their advance." Two galleries, however which had been driven beneath the bastion of England eluded his vigilance and two fearful explosions and This event was in 1522 , at Rhodes, when besieged by the Turks.

B. V. F.-The principle of the acoustic telephone is no doubt very old. It was one of the peculiar traits of our beloved aborigines to listen with their ears to the ground to the movements of their enemies or of animals. They could hear the tread of a horse at a great distance. This was one of the surprises to the early mines an the country. It is in common practice in tras, and many practice it by telling the approach

The possibilities of telephonic information, as $\mathrm{em}$ bodied in the acoustic telephone of the present day, were only an outcome of the application of the ear to the wall, and were probably intensified by the use of a stick of lance wood thrust into the ground in the counter mine and a drum head laid against the end

the stick, with the ear behind the drum head.-ED.

sibley College of Mechanical Engineering.

The number of students registered this year in Sibley College of Mechanical Engineering, Cornell University, is something like 450 , including a considerable number of graduates from other colleges taking, in most cases, advanced work in research and higher engineering and of the whole list, nearly one-half are selecting the electrical work in specialization, the others dividing between general engineering, steaw and naval engineering, and other special lines of work. The upper work in the number of about 200 , are all taking siderably extended to meet this large demand. At the

he rails. The sides and 2 of the cars are of glass as end of the year it will have its 200 men assigned to work in strength of ma. work in strength of ma. of research in that genof research in that gen-
eral direction, to engine and boiler testing, and to a great variety of spe cial investigations. The outfit will include an experimental engine of 200 horse power, to be contructed fro to Reynolds' designs by the E. P. Allis Co., of the E. P. Allis Co., of of swaller and specially constructed engines and boilers, including $\mathrm{t} \mathrm{h}$ 500 horse power heating plant of the university collections of $\mathrm{s} t \mathrm{e} \mathrm{a}$ pumps and injecto a plant illustrating Hinit analysis; several air aud gas engines, including all the usual types; turbinesand rotary pumps; of 15,000 to 20,000 pound capacity, others of 40,003 and 50,000 , one of 100 . 000 , one of 200,000 , and

from the ordinary loco-
wotive. Each engine weighs 26 tons, and is capable $\mid$ far as possible, so as to give free observation without. |limit; with special machines for transverse and tor-

\begin{tabular}{l|l|l|l|l|l} 
motive. Each engine weighs 26 tons, and is capable & far as possible, so as to give free observation without. & limit; with special machines for transverse and tor- \\
of carrying two coaches. There is no tender, the water & The wood work within is handsomely finished, and the & sional testing; some of each kind having autographic
\end{tabular} \begin{tabular}{l|l|l} 
of carrying two coaches. There is no tender, the water & The wood work within is handsomely finished, and the & sional testing; some of each kind he \\
being carried in two saddle tanks of a capacity of 600 & upholstering of old gold plush. The seats are designed & registry of very ingenious designs.
\end{tabular} \begin{tabular}{l|l|l} 
being carried in two saddle tanks of a capacity of 600 & upholstering of old gold plush. The seats are designed \\
gallons on either side of the engine, while a box at the & to set level on the average grade of 16 per cent. The
\end{tabular} rear carries 11/4 tons of coal, sufficient for one round cars are pushed, not drawn, by the engines, and are trip. There are three water stations on the route, be- not coupled to the engine, but have simply buffers to sides the one at the lower station.

The cylinders of the engine are 17 inches by 20 l are locked while the train in in motiun.

A Goon paste for labels for specimens: Starch, $2 \mathrm{dr}$. white sugar, $1 \mathrm{oz}$; gum arabic, $2 \mathrm{dr}$.; water, $q$ s. Dissolve the gum, add the sugar, and boil until the starch is cooked. 
How Crucibles Are ruade. BY E. c. HOVEY.

The manufacture of fireproof pottery in the United States is a comparatively limited business. There are
large regions, and possibly entire States, where not single crucible is used. There are probably not more than $\$ 1,500,000$ at present invested in this line of masufacture in America. There are three factories in Philadelphia, two in Pittsburg, two in Jersey City, two in delphia, two in Pittsburg, two in Jersey City, two in
Taunton, Mass., one each in St. Louis, Mo., MascouTaunton, Mass., one each in St. Louis, Mo., Mascou-
tah, Ill., and Bridgeport, Conn. Some of the largest firms carry on numerous branches of business besides, while others, as, for instance, the Bridgeport company, make nothing but crucibles. Limited as this business
is, it has features of special interest. For one thing, it is believed that all the large plumbago crucibles used in this country are home-made, the only imported ones being the snuall "sand erucibles" used by manufacturing jewelers, chemists, and assayers. This is but parting jewelers, chemists, and assayers. This is but partof 20 per cent (not affected by the McKinley law); for of 20 per cent (not affected by the McKinley law); for
even if admitted free, the foreign goods could not even if admitted free, the foreign goods could not come into competition with those of home manufacture,
since the labor item is so much less than the cost of waterials, and the latter can be had as cheap here as in Europe.

The ingredients going to make fireproof pottery are as follows: Plumbago, 50 per cent; blue clay, 30 per cent ; kaolin, 12 per cent ; fire-sand, 8 per cent. These proportions vary with the quality of the materials used, so that the above formula undergoes continual modification, according to the judgment of the wixer.

True economy requires that none but the very best materials should be employed in making a vessel that has to be subjected to the most intense heat. Hence a few words are here in place as to the sources of viceable, as any impurities in it would either melt or burn out, and thus spoil the crucible. Probably a chemical analysis would show that hundreds of tons of the plumbago used is from 99 to $991 / 2$ per cent pure the plumbago used is from 99 to $991 / 2$ per cent pure
carbon. In other words, the main ingredient of the carbon. In other words, the main ingredient of the
plain, homely crucible is identical with the finest diamond in substance, differing from it merely in form. None has yet been found in this country that can stand the prescribed test. Hence what is used is imling in purity and fiber any other known deposit. The principal earth combined with the plumbago is the German blue or pipe clay, from Gross Almerode, in Hesse, where it is found in an elevated plateau, being apparently a lacustrine deposit. Its peculiarity is apparently a lacustrine deposit. Its peculiarity is that vessels made from it can be heated without fusing
to from 4,000 to 6,000 degrees Fahr., and can also be to from 4,000 to 6,000 degrees Fahr., and can also be
plunged cold into the furnace or thrown hot from it without cracking-a treatment that French and American clays will not stand.

Clays found in Missouri were thought, at one time, to meet the requirements, but on trial it was found that they would not answer. Both the clay and the plumbago are brought in sailing vessels at a low rate, and free of duty. A curious fact about the clay is that it is eut in blocks, each of which bears the stamp of the municipality owning the deposit. Once a year they have a public meeting and fix the price for the com-
ing year, after which the trade is free to all the world. ing year, after which the trade is free to all the world. The kaolin used in crucible making resembles the china clay used in fine pottery, and is found in various parts of our country, there being large deposits of it in New York, New Jersey, Maryland, South Carolina, is preferred. The fire-sand used is nearly pure silica, and in any event must be free from iron. Excellent sand for the purpose is to be had at Gayhead, Martha's Vinevard, and on Long Island, near Glen Cove.

The process of manufacture is seemingly quite simple, as explained to we at the Bridgeport Crucible Works, by the courtesy of the manager, Mr. W. T. Macfarlane. The ingredients named are mechanically : combined, the mass is kneaded and spun up into shape, short as this process is, it involves its perplexities. Results are governed by obscure and often elusive causes sults are governed by obscure and often elusive causes, and any consequent disappointment may involve
serious loss. The continually shifting proportions tax the best trained judgment. For instance, the
plumbagoes, while constant chemically, vary exceedplumbagoes, while constant chemically, vary exceed-
ingly physically, and the successful manufacturer must vary his combinations accordingly. The clays too must fit the changing character of the plumbago, and under which it is to be used. Admirable results may be had in melting one sort of metal in a vessel that would really be worthless for another. A combination would really be worthless for another. A combination
containing a tough fibrous plumbago will give a far different result from that to be had with the same mixture where the plumbago, though chemically iden-
tical, is crumbly and brittle. The crucible maker of modern times can readily understand the superstition of the old alchemists that originated the very name of his goods, in conformity to which the sign of sel before it was put into the furnace, in order to prewe see that its contents are made up of bits of mineral degree of fineness by French buhr stones. The pulverization determines the porosity, on which the ability verization determines the porosity, on which the ability
of the crucible to stand heating and cooling largely the melted metal leaks out as if run through a sieve. The German clay likewise is crushed and pulverized, after having gone through a preliminary process of
drying in dry closets, each holding 20 tons. The different flours and grades are stored in separate bins. Then follows the extremely delicate and important task of mixing the ingredients, which is seen to by the manit is kneaded by rotating blades till it is homogeneous, after which it is stored in
room ready for the wheel.

There is no need of $\mathrm{my}$ digressing here to describe ancient and least modified of all arts. The wheel on which the smaller crucibles are spun is almost the exact counterpart of that known to have been used by the prehistoric Neolithic man. But for larger vessels, inpecial contrivances have been invented to assist the
potter in giving shape to the mass of clay at his disposal. He first kneads it over and cuts it through and through with wires to detect the presence of bits of ron, gravel, or other foreign substances. Having patted the mass into an oblong lump, he next drops it into prepared mould. This used to be made of plaster of
ome time before being removed. Of course in a large establishment the number of plaster moulds needed ith loose cloth, so clamped as to be able to be taken away as soon as the pot is shaped, leaving it intact. One mould way thus be kept constartly in service, and r more rapid and satisfactory work is done, because the dough does not need to be so wet as in the old proess. After partly drying, the crucibles are pared to a hey go to the annealing ovens, which are at first very gently heated, but afterward to an intense degree. It discharge of a cannon. The sound crucibles, after cooling and due inspection, are suitably packed for shipment. Even after they get into the hands of the bras ounders, or others who intend to subject them to a ferce heat, the pots are stacked for supplemental seadone. The best crucibles are expected to stand sixty or seventy rounds for melting purposes. The fragments of those used up in the brass foundries are ng cleaned from slag and ground over again for use in aking a cheaper grade of firepots.

In view of the rapidly increasing demand for all coneivable compounds of zinc, copper, silicon, aluminum, crucibles will become an industry of constantly growing importance. It is essential to the finest results that the materials of which the crucible is made should the metals should not undergo any degree of chemical absorption by the ingredients of the pot. To some ex steel, which does absorb a certain amount of carbo
from the plumbago. For this reason superiority i serted that makers of crucible steel make due allowree melter, readily absorbing and transwitting heat burned out, and too much fuel consumed in proportion to the results gained.

In conclusion we may sum up the qualities of a perect crucible in the words of $\mathrm{Mr}$. Macfarlane: " must combine the highest refractibility with the abilistand a high melting heat; it must not injure the through the pores; and it must absorb and transunit
heat readily." The only true test is actual use. And
Crawford \& Valentine, as the firm name was made to

vent its being bewitched by the demons of the fire 1 consequences, too high an estimate can hardly be put Following a cask of plumbago from the wharf where upon the need of skill, experience, and sound judgment it is landed to the grinding room where it is dumped, in crucible making. of all sizes. These are inspected and assorted. Then depends. If the flour is too fine, the contraction is not taken up in itself as it should be, and the vessel
will crack after being used only once or twice. If on will crack after being used only once or twice. If on
the other hand it is too coarse (as occasionally happens), ager himself, who is so very careful in this as to weigh down to a quarter of a pound in a ton and a half of
material. The wass next goes to a mixing tab, where the simple wysteries of the potter's art-the most tended to hold from 400 to 600 pounds of melted metal,
special contrivances have been invented to assist the would be great, and would occupy much space for storproper finish and placed on shelves in large drying
rooms to season for from ten to twenty days. Then occasionally happens that a "green" pot gets by misteam, it is rent to fragments with a report like the
the treated as worthless; but those used in making steel not attack nor affect in any disastrous way the metals tent this is unavoidable; as in the manufacture of from the plumbago. For this reason superiority is
claimed for the Sheffield steel, because it is not melted in plumbago vessels. But on the other hand it is as-
serted that makers of erucible steel make due allowaddition to its other qualities the crucible should be a ty to pass through enormous gradations of heat with-
out warping or cracking; it must be firm enough to metal made in it, nor subject it to loss by leakage as failure in actual use may involve serious and costly $\left.\right|_{\text {read by our printers. }}$

\section{Astronomical Phenomena during the Year 1891}

The principal phenomena predicted ior the year 1891 the eclipses, two of the sund two of the moon, pearance and reappearance of Saturn's rings. Of these the last two will excite the most interest.

A total eclipse of the moon, May 23, will be invisible in the United States, but visible generally throughout
the western part of the Pacific Ocean, Australia, Asia, he western part of
frica, and Europe

An annular eclipse of the sun, June 6, will be visible partial eclipse in the western part of the United States,

in British America, Europe, and Siberia.

A total eclipse of the moon, November 15, will be visile throughout North and South America, Asia, Africa urope, and the Atlantic Ocean. It will begin at $3 \mathrm{~h}$. $6 \mathrm{~m}$. and end at $9 \mathrm{~h} .3 \mathrm{~m}$. P. M. central time. We extars during this eclipse, and a list of the stars which
thect later to give a chart of the moon's path among the will be occulted.

A partial eclipse of the sun, December 1, will be visible only in the souther
the south polar region.

The transit of Mercury across the sun's disk will take place on May 9, beginning at $5 \mathrm{~h} .55 \mathrm{~m}$. and ending at the United States and throughout the western part of North andSouth America and Asia. The whole tran-
sit will be visible in Japan, China, Eastern Siberia, Australia, and the Malaysian Islands. It is not likely hat any expedition will be sent out for the purpose of parallax, for which such great pains have been taken in bserving transits of Venus, has, by other means, been determined with much greater accuracy than could be ttained from transits of Mercury. There are, however interesting questions as to the planet's appearance
during transit, its atmosphere and motion. No one who has the opportunity to observe this transit should neglect to make all the use possible of it.

Professor G. W. Coakley, of the University of New ork, has computed the times of the contacts for several will be found very useful to those wishing to observe the transit.

On September 22 the earth will pass through the lane of Saturn's rings. The rings then, in telescopes of sufficient power to show them, will appear as a fine 30 the earth will be above the plane of the rings, while the sun will be below that plane, shining upon the south side of the rings. The rings then should entirely disappear, except the very fine thread of light which October 30 the sun will be on the north side of the plane of the rings, so that its light will illuminate the ame side of the rings at which we look. Many intersting observations were made at the time of the disppearance of Saturn's rings in 1878, and, although the position of the planet will be very unfavorable, it is to and accurate data obtained for the solution of the problems connected with the rings. Saturn will be in
conjunction with the sun on September 12 , so that at the time of the disappearance of the rings it will be very close to the sun and can be observed only very near the horizon.-Sidereal Messenger.

\section{Kola.}

The kola seeds can be procured in Venezuela. Karsten, in his "Flore de Colombie," describes the plant as growing wild in the moist, hot woods near the southern coast of Venezuela, but different authors suppose
it was introduced by African negroes at the same tim that it was taken to Martinique. The French have recently introduced the kola to Guadaloupe and $\mathrm{Ca}$ enne, where it flourishes in moist lands at or a little bove sea level. It begins to yield a crop of fruit in uch situations about its fifth year, and later will yield over $100 \mathrm{lb}$. of seeds annually. I should doubt the germination of seeds procured here, as they have,
I presume, been brought from England, and it is impresume, been brought from England, and it is impossible to say how long they have been there from Africa. The tree is the Sterculia acuminata, or true difficulty is experienced in keeping the pods from moulding ; but if properly packed they would, I should think, be easily propagated by soaking the nuts for a day and night in warm water, or in a weak solution of mmonia. Nicolas Pike.

THE work on the Brooklyn aqueduct described in the SCIFNTIFIC AMERICAN of January 3 is being exe0:53 P. M. central time. It will be partly visible in circumstances, for such observations would be of value only in deterwining the place of the planet. The solar be hoped that many of them will be repeated this year, 


\section{Miscellaneous Notes.}

Forest Park, St. Louis, is one of the finest parks in the world. It contains two square wiles, or 1,280 acres, of forest, glade, lake, and river, with twenty miles of roads and walks.

The Bell telephone patent monopoly in England has expired. The patent there was granted tor 14 years. Cheap telephones will now prevail in England the same as in Germany, where Bell failed to obtain a patent. as in Germany, where Bell failed to obtain a patent. 1893, having been originally granted March 7, 1876, for a term of 17 years.

a term of 17 years.
The new U. S. protected cruiser Newark on her recent trial, December 22,1890 , developed a speed of $19 \cdot 6$ knots, under forced draught, during four hours' run. This is one of our latest and best eruisers. She is $327 \mathrm{ft}$. 7 in. extreme length, $49 \mathrm{ft}$. beam, displacement 4,090 tons, 8,500 to 9,000 h. p. The new English built Argentine protected cruiser 25 de Mayo on her recent trial trip attained a speed of $20^{\circ} 75$ knots with natural draught, and $22 \cdot 43$ knots with forced draught. This ship is $325 \mathrm{ft}$. extreme length, $43 \mathrm{tt}$. beam, 3,200 tons displacement, 8,500 h. p. natural draught and 13,800 h. p. forced draught. It will be seen from the foregoing that the English built ship is far superior to the or other the latest U. S. vessels are always prone to be behind the latest European vessels in those essential qualities, power and speed. Can anybody explain the qualities, pow

What is the best position for the bridge aboard a war ship? Our naval architects are of opinion that it should be well forward, in some cases, as on the Yorktown and Concord, setting it up over the topgallant forecastle, and on the Baltimore and Philadelphia jamwing it still further up into the bows. 'The British, on the other hand, think the waist or 'midship section the best place for it; holding that a commanding officer should be able to con his ship without facing about. This is a recommendation, surely, but the advantages of having a clear horizon, an unobstructed view ahead, will appeal to the nautical mind. A bridge forward of will appeal to the nautical mind. A bridge forward of the mizzen or even between fore and main wasts never
affords an unbroken view; in maneuvering, or, worst of all, in meeting other craft or working in a narrow channelway, interposing objects, such as masts, yards and stays, seriously incommode and at times obscure the view. In practicing a crew at working ship or guns, a bridge well aft, as in the British method, affords a better opportunity for critical study, and perhaps, as the British designers allege, in the thick of battle gives the commander a better control of his batteries, but for general service, whether in combat, maneuvering or cruising, the forward position would seem to promise the best results.

The Projected Balloon Voyage to the North Pole. The two daring aeronauts who propose to make a in the Scientific American of December 20, 1890, are meeting with many discouragements. The French Society of Aerial Navigation has pronounced unanimously against it. At a recent meeting of the society in Paris, the president, Mr. Mage, editor of Cosmos, in Paris, the president, Mr. Mage, editor of Cosmos,
made an address which was quite disheartening to the projectors of the enterprise. He advised them to make better use of their energyanddevotion to science than to attempt to reach the North Pole by balloon. Mr. Mage said it was impossible to believe the gentlemen would succeed. All our information about the prevailing winds in the polar regions indicates that each extremity of the earth's axis is a region of circular wind currents. There is little prospect that the wind would carry balloon travelers to their destination. Then, even in summer, a very low temperature prevails, heavy falls of snow are frequent, and it is diffvails, heavy falls of snow are frequent, and it is diffi-
cult to believe a balloon could remain in midair while cult to believe a balloon could remain in midair while
heavily weighted with snow. Frost upon the ropes and other parts of the rigging would wake the management of the balloon extremely difficult, if not impossible. The land or water surface would for days at a time be obscured by heavy mists. The compass would be useless, and the voyagers would have to try to direct their movements by the stars, an art in which balloon travelers are not proficient. Mr. Mage's remarks were endorsed by the entire society.

Mr. Hermite, who, with Mr. Besancon, projected this daring voyage, said in reply that he and his comrad intended next summer to go to Spitzbergen and launch pilot balloons for the purpose of learning all they could at that point of the direction of the prevailing winds. If the result of these experiments is favorable, they will return to France and prepare to make their polar voyage in 1892 . If the results are unfavorable, they will renounce the expedition. He did not able, they will renounce the expedition. He did not
believe that the difficulties in the way of balloon believe that the difficulties in the way of balloc
traveling were so great as the president believed.

Another speaker said that during the summer, at a mean altitude not exceeding 3,500 feet, and the mean temperature during his journey was not less than $40^{\circ}$ below the freezing point, and yet his voyage was across
the southern part of the island. It was the sheerest folly to suppose a balloon, which has as much rigging as a ship, could successfully be carried across the

\section{A COTTON CHOPPER AND CULTIVATOR.}

The illustration represents a machine provided with hoes for chopping cotton or other plants, cultivators or working the plants, scrapers to clear the earth in advance of the hoes, and harrow teeth for use when Anderson, of Jackson, Tenn. Upon the bottom of the main frame are two diagonal side beams, near the forward end of each of which a scraper is adjustably secured. Farther back on each beam are harrow teeth, ing in opposite directions, these teeth being preferably so attached to the beams as to be vertically adjustable. In the rear end bar of the main frame, at each side of the center, a series of cultivator blades is secured, these blades preferably being of what is known as the "elk's foot" pattern. The rear axle is journaled in
" "elk's foot" pattern. The rear axle is journaled in
vertically adjustable boxes sliding in hangers attached the main frame, and a bevel gear on this axle meshes with a similar gear on a longitudinal shaft, the bearings of which are capable of vertical movement, and upon this shaft is the chopper. The hub of the chopper has radial arms with longitudinalgruoves in which the shanks of the hoe blades are adjustably arranged, one hoe to each radial arm. Lomated longitudinally over the main frame is a lifting frame having near its rear end downwardly extending hangers which receive the rear axle, and by manipulating an adjusting screw the rear end of the frame is elevated, with the axle and ngitudinal shaft, thus regulating the depth of cut of

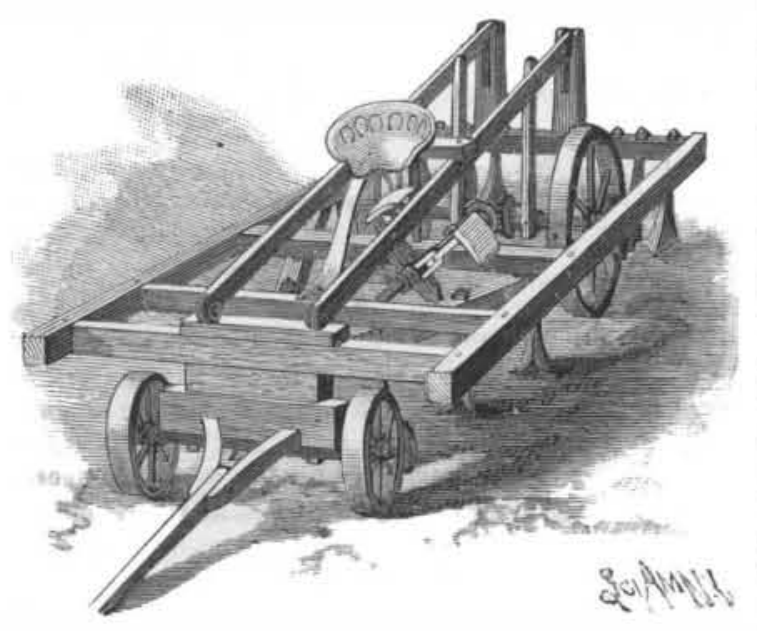
ANDERSON'S COMBINATION COTTON AND CORN HOE
AND CULTIVATOR.

the scrapers and rear cultivators. The depth to which the hoes shall cut is regulated by the adjustment of the hoes upon the arms of their carrying hub. As the machine is drawn forward, the scrapers clear the
earth in advance of the hoes, which revolve rapidly to remove the surplus plants, while the cultivators at the rear pass between the remaining plants and throw up earth over their roots. When the hoes are in operation the harrow teeth are preferably adjusted so as not to touch the plants or the ground, these teeth being wore especially adapted for use in connection with the rear cultivator teeth only, the longitudinal hoe shaft bein cultivator teeth only, the longitudinal hoe shaft bei
then thrown out of gear with the rear driving axle.

\section{New Experiments in Magnetism.
BY A. E. DOLBEAR.}

It has long been known that a common sewing needle will float if carefully placed upon a surface of
water; also, that if the needle be magnetized it will assume a position in the magnetic meridian. Iron and steel filings will also float, and they can be sprinkled upon the liquid surface nearly as well as upon a solid. If the pole of a magnet be brought near to the floating particles, they will respond to the solicitations
magnetic field in a very free and easy manner.

Let a strong U-magnet have its poles brought near to the iron filings, and they .will at once arrange themselves in the well known forms, the lines being plainly seen. The induction, of course, causes adjacent particles to assume opposite polarities and consequently
touch each other when free to move. If, now, the field magnet be removed, the filings will retain their arrangement, and if it be in a vessel large enough to permit the rotation of the whole body, it will swing into the magnetic meridian if it did not happen to be in it at first, thus showing that the arrangemen the magnet, and that as a whole it possesses

Now bring gently near the floating magnet one pole
Notic of a bar magnet. If this be presented to one of the poles of the particles it will be attracted toward it, and the whole body will rotate more or less; but this must
be done slowly, else the arrangement of filings will be broken up. The opposite pole will, of course, under similar conditions, exhibit repulsive action, and the whole will swing about. If, now, the magnetic pole be brought near to the a small proportion of the true berries before selling. middle of the arranged filings, some of the groups wil be more or less disintegrated from the rest, and will ro tate upon a vertical axis and quite turn round. The opposite pole presented will cause them to rotate back again. Great numbers of these can
thus whenever a pole is thus presented.

This phenomenon is evidently precisely the same in character as that illustrated at length by Ewing in his late investigations into the constitution of magnets. werein he used small magnetic needles mounted upon pivots. The above experiments can be tried in a sauce water, but the whole is capable of being projected with the vertical attached to a lantern, and the move-
ments of all sorts seen upon a screen with ease and very little painstaking. -Electrical Engineer.

\section{The sturtevant Rotating Battery for Harbor}

For the defense of harbors where the ground admit of the formation of an artificial island, Thos. L. Sturtevant, of South Frawingham, Mass., proposes the following plan :

An island of generally circular form is established which incloses a circular reservoir of water. Protection is afforded the reservoir by inclined armor plates buried under the earth and surrounding it by a protective
subterranean cave. Within the reservoir a circular floating battery is established, pivoted or anchored by a central pin driven into the bottom of the reservoir. The battery has a roof like an inverted saucer, and is perforated for heavy guns. The armor plate may be of the heaviest kind, as the displacement way be in-
creased to any desired extent. The roof is extended creased to any desired extent. The roof is extended
beyond the sides of the tunnel, so as to cover nearly the entire area of the reservoir. A sluiceway is carried out under the surface of the island to admit water if cape. In use the entire battery is rotated by hand or by power, so as to bring its guns to bear on any desired point.

\section{Trial Trip of the Gunboat Concord.}

This new steel vessel made a successful trial trip on Long Island Sound, January 13 . She is a sister ship to the Yorktown, described in the ScIENTIFIC AMERICAN
SupPLEMENT, No. 687. The trial lasted four hours, during which the engines were required by the contract to develop an average of 3,400 horse power, with a bonus of $\$ 100$ for each horse power above this numery easily fulfilled the requirements, in the opinion of the engineers, and the vessel is thought to have earned a prewium of some $\$ 16,000$.

The engines worked beautifully with no water on the bearings and the throttle wide open all the time. The steam pressure averaged 160 pounds for the four hours. The average number of revolutions of the engines was
lightly over 150 . The boilers worked well also, keepng a steady pressure of steam all the time, with about two inches of air pressure in the blower ducts. The average speed made was 15.8 knots per hour by ressel, the actual speed was computed to be 16.8 vessel,

The Concord has the closed ash-pit system of forcel raught. She is a twin-screw, coal-protected steel gumboat, with poop and forecastle decks and an open gun deck between; length, 226 feet; mean draught, 1 feet ; displacement, 1,700 tons. There are two horizontal triple expansion engines in separate water-tight ders have a thirty-inch stroke. The engines are fitted with the Marshall valve gear and piston valves. There are four steel boilers, diameter 9 feet 9 inches, and length 17 feet 9 inches. Each has three corrugated steel furnaces. Grate surface total, 220 square feet. Total weight of machinery, with boilers filled, 331 tons. The propellers are of manganese bronze, three-bladed, and of the modified Griffith type. Diameter, 101/2 feet wean pitch, $12 \frac{1}{2}$ feet

The contract for this ship was made November 15 1887, with the Quintard Iron Works, ind she was to contractors were subject to delay on account of difficulty in getting waterial.

When put in commission she will have a battery of six 6 -inch breech-loading rifles and eight rapidfire guns and revolving cannon. She has, besides,
eight torpedo-launching tubes. She is rigged as hree-masted schooner, spreading 6,300 square feet o ail, and will have a crew of 150 men.

M. Ludovic JAMmes, in the Revue diHygiene, eports that commercial travelers are offering imitation coffee berries which can be sold so low to dealer $s$ to yield a profit of 100 per cent. These berries ar made artificially from vegetable glands and the flou f some cereal. This mixture is placed in a mould and ried. The slit in the false berry is neither so long or deep as in the real berry. The color is well imitated, broken with the teeth. These berries are mixed with 